\title{
Cycads: evolutionary innovations and the role of plant-derived neurotoxins
}

\author{
Eric D. Brenner, Dennis W. Stevenson and Richard W. Twigg
}

The New York Botanical Garden, 200th St. and Kazimiroff, Bronx, NY 10458-5126, USA

Cycads are an important relic from the past and represent the oldest living seed plants. Cycads have been instrumental in our understanding the evolution of angiosperms and gymnosperms because they have recognizable morphological characteristics intermediate between less-recently evolved plants such as ferns and more-derived (advanced) plants including the angiosperms. Cycads also produce several compounds that are carcinogenic and neurotoxic. Because of their unique placement in terrestrial plant evolution, molecular studies should help to define the origins of structures that led to the rise of seed plants and the role of neurotoxic compounds that are found in cycads.

The eminent cycadologist Knut Norstog said 'I have sometimes used the analogy of the Rosetta Stone for the fund of information stored within the cycads and its importance to the interpretation of plant biology. This discovery made it possible to decipher Ancient Egyptian writing and revealed many aspects of this great culture that were previously unknown. In a similar way, the ancient structures and developmental pathways of cycads enable us to make connections between the early origins of seed plants and their present-day counterparts' [1].

As plant biologists, we are fortunate that an ancient order of gymnosperms has endured for nearly 300 million years. These plants, the Cycadales, commonly known as cycads, are popular among horticulturalists because of their elegant, PINNATELY (see Glossary) compound leaves and giant cones (Fig. 1). Cycads, once found world-wide, are today restricted to warm climates in both the New and Old World. One probable explanation of why cycads have survived is that they are well fortified against environmental threats. They survive drought, fire and are remarkably resistant to pathogens and predators [2]. Much of this endurance can also be ascribed to the biosynthesis of a variety of protective, secondary compounds [2].

Some secondary compounds found in cycads have also been linked to neurological disorders. The 'Zamia staggers' is a condition of ataxia in the hind-limbs of cattle and sheep that graze on cycads [2,4]. More mysterious is the heightened presence of Alzheimer's and Parkinsonian's dementia among people that eat cycads [5]. This disease, known as 'Guam's dementia', has been linked to the presence of neurotoxic compounds synthesized by cycads [6-8].
The oldest cycad fossils date from the Upper Paleozoic 265-290 MYA (million years ago) [9,10]. They reached dominance in the Mesozoic, a time considered not only as 'The age of dinosaurs' but the 'Age of cycads' as well. Cycads are a combination of PLESIOMORPHIC and APOMORPHIC traits, which are useful for studying plant evolution. Traditional paleontological studies place cycads within the earliest group of seed plants called the 'cycadophytes', which also include the Cycadeoidales and the original seed plants - the seed ferns (Pteridospermales) - leaving cycads as the only surviving group from this ancient stock [11]. Modern cycads comprise 11 genera (Fig. 2a). Using available extant and fossilized morphological characteristics, [12] cycads can be combined with extinct genera to create a phylogenetic tree (Fig. 2b). With some exceptions [13,14], most phylogenies place the Cycadales as the basal order of the gymnosperms [12,15-17] with Ginkgoales, Coniferales and Gnetales as

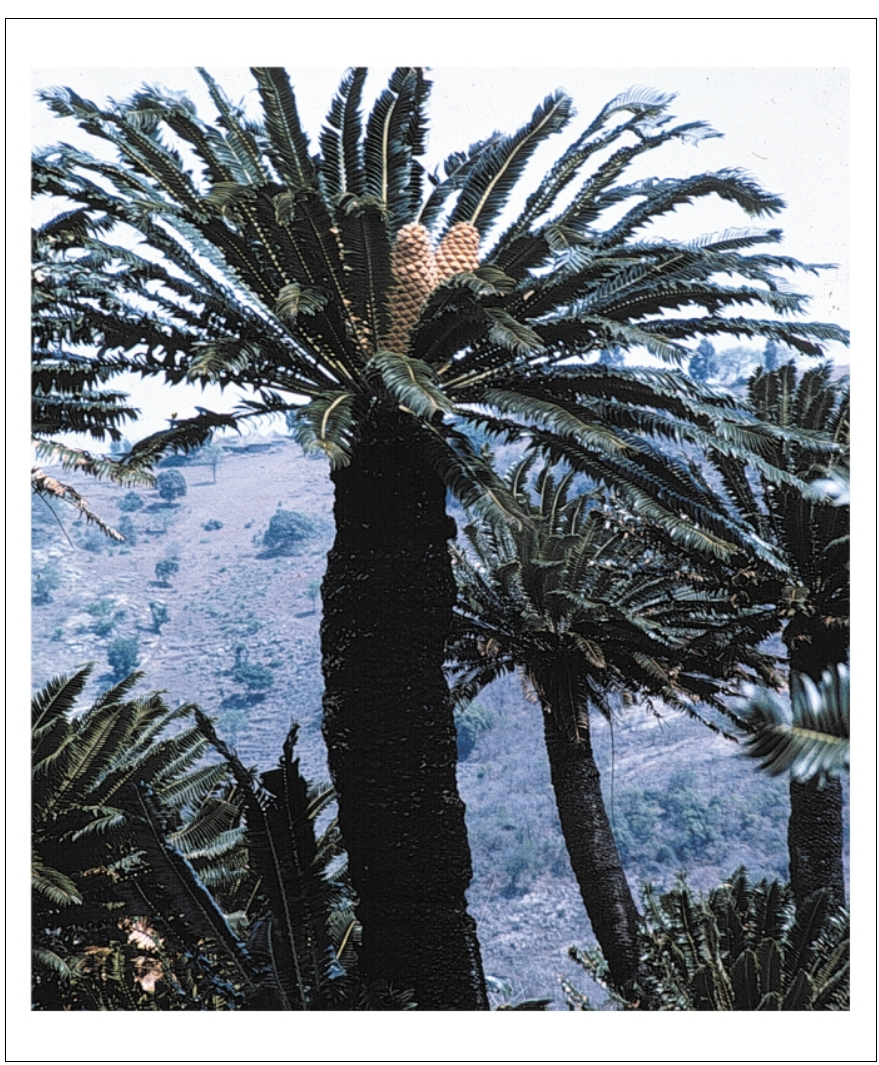

Fig. 1. Fertile Encephalartos transvenosus growing in Transvaal, South Africa. 


\section{Glossary}

Agravitropic: Negatively geotropic; negatively gravitropic; developing in an orientation contrary to gravitational force, as with cycad coralloid roots.

Angiosperm: A class of plants bearing ovules (seeds) within a carpel. Gymnosperms do not have a carpel.

Antheridia: The male sex organ of lower plants.

Apomorphic: Derived character or character state.

Archegonia: The female sex organ of the lower plants and most gymnosperms, including all cycads.

Axillary: Arising from tissue in the axil between a stem and leaf, as a lateral branch.

Circinate vernation: Rolled in a coil-like manner with the apex innermost, as in leaflets of emerging leaves of $C y c a s$ species and the leaves of ferns.

Coenocytic: Describing a cell containing many nuclei that lacks separating cell walls.

Coralloid roots: Apogravitropic root with the potential for hosting symbiotic Cyanobacteria.

Entire: With a continuous margin; not toothed or lobed; without incisions of any kind.

Entomophily: Pollen transfer brought about by insects.

Glutamate receptors: Glutamate activated, membrane-bound proteins that are either ionotropic or metabatropic transmitters of cell signals. Also used to refer to plant genes that are highly similar in sequence to animal glutamate receptors.

Gymnosperm: Loosely related (polyphyletic) group of seed-bearing but nonflowering plants, including cycads, conifers, Ephedra, Ginkgo, Gnetum and Welwitschia (Gnetales) together with various extinct taxa. All bare ovules, later seeds, without an enveloping carpel.

Idioblast: Specialized cell with inclusions. In cycads, they store toxins, possibly as an herbivore deterrent. A cell without known function.

Integument: Outer covering of an ovule, forming the layers of the seed coat at maturity. The cycad seed coat comprises three layers: the sarcotesta, sclerotesta and endotesta.

Isotomous: Dichotomous branching that results in two branches of equal length.

Megagametophyte: Mass of haploid cellular tissue surrounding the embryo in a gymnosperm seed; analogous in function but not in origin to the endosperm of angiosperm seeds.

Megasporangium: Structure that makes the megaspore that gives rise to a female gametophyte. In cycads, the megasporangium is the nucellus of the ovule.

Megasporophyll: Sporophyll bearing one or more ovules that will potentially become seeds.

Nucellus: Tissue in the ovule that encloses and supports the embryo sac. See megasporangium.

Ortholog: Genes from separate species that have the same biological function. Both are typically evolved from a common ancestral gene.

Pinna (plural pinnae): Primary division of a compound leaf or leaflet.

Pinnate: Feather-shaped; typically a leaf with leaflets or pinnae on either side. Plasmodesmata: Channels, lined with the plamalemma, that interconnect the cytoplasm of adjacent cells facilitating intercellular communication and transport of materials.

Plesiomorphic: Ancestral or underived character or character state.

Sister group: The group most closely related to a monophyletic group.

Spermatophyte: Any seed-bearing plant, including all gymnosperms and angiosperms.

Sporophyte: The diploid generation in a plant. The sporophyte arises from the fusion of the spermatozoid with the egg in the ovule. The sporophyte reaches maturity to produce a new set of gametes by meiosis.

Sporophylls: Modified leaf bearing reproductive structures. See megasporophyll.

Synapomorphy: Shared, derived character state; an apomorphy that unites two or more taxa into a monophyletic group.

more advanced (Fig. 2a). This likely placement defines cycads as the SISTER GROUP to all living seed plants.

Analysis of cycads has helped us to address two of the most important questions in plant science: first, how did the SPERMATOPHYTES arise? Second, when and how did the ANGIOSPERMS appear and rapidly proliferate? Darwin called this the 'abominable mystery'. Many antecedent structures found in cycads are similar to key innovations that paved the road toward the evolution of both gymnosperms and angiosperms.
Considering how important cycads are to our understanding of plant evolution and the environmental causes of neurological disease, it is odd that cycads are largely ignored in new areas of plant research, particularly molecular evolution and development. This oversight needs to be corrected. Now that we are entering the post-genomic era, we can address classical botanical questions using new genomic tools $[18,19]$. Thus, the purpose of this article is threefold in its attempt to outline some of the unique features of cycads ranging from general morphology to biochemistry: (i) to assess the characters in cycads that are important in seed plant evolution; (ii) to define how a molecular approach might be used to study the development of some of these 'innovations' in cycad; and (iii) to discuss the presence of neurotoxic compounds in cycads, and speculate on their endogenous role in plants.

\section{Cycads and evolution}

In this article, we describe some characteristics of cycads that are useful in understanding the rise of seed plants. Some of these features represent innovations that led to the emergence of the Spermatophytes. Other features are reminiscent of those in less evolved, non-seed plants that are no longer found in angiosperms. For example, some characteristics of cycads, such as motile gametes, are indisputably plesiomorphic characteristics, similar to those in early spermatophytes such as the seed ferns [20], which have been studied by botanists for many years. Using molecular and genomic technology, we now hope to gain insight into the mechanisms controlling the appearance and disappearance of traits that led to the rise of seed plants.

\section{Innovations in reproduction Ovules}

To understand seed evolution, one must first understand the origin of the ovule. The ovule (Fig. 3a,b) is a MEGASPORANGIUM (NUCELlUS) enclosed by a sterile INTEGUMENT. In non-seed plants, the gametophyte is free living and the ARCHEGONIA and ANTHERIDIA are exposed to the environment. Fertilization is water based and multiflagellated gametes (sperm) produced by the antheridia swim into the archegonia where the egg is present at the base. Consequently, ovule evolution required the retention, reduction and reorganization of the gametophyte within the maternal SPOROPHYTE as well as the development and proliferation of the integument to enclose the nucellar borne MEGAGAMETOPHYTE [21]. (The megagametophyte in gymnosperms is recognizable in Pinus as 'pine nuts', which can be eaten raw or roasted. In cycads the starch-rich megagametophyte is also eaten but must be detoxified before consumption).

Thus, seed evolution required a dramatic reorganization of the gametophyte. In seed ferns (now extinct) and extant gymnosperms, including cycads, the archegonia are still a recognizably distinct organ (Fig. 3a) within the ovule-borne megagametophyte. In angiosperms, and in some members of the Gnetales, archegonia are absent [21]. 


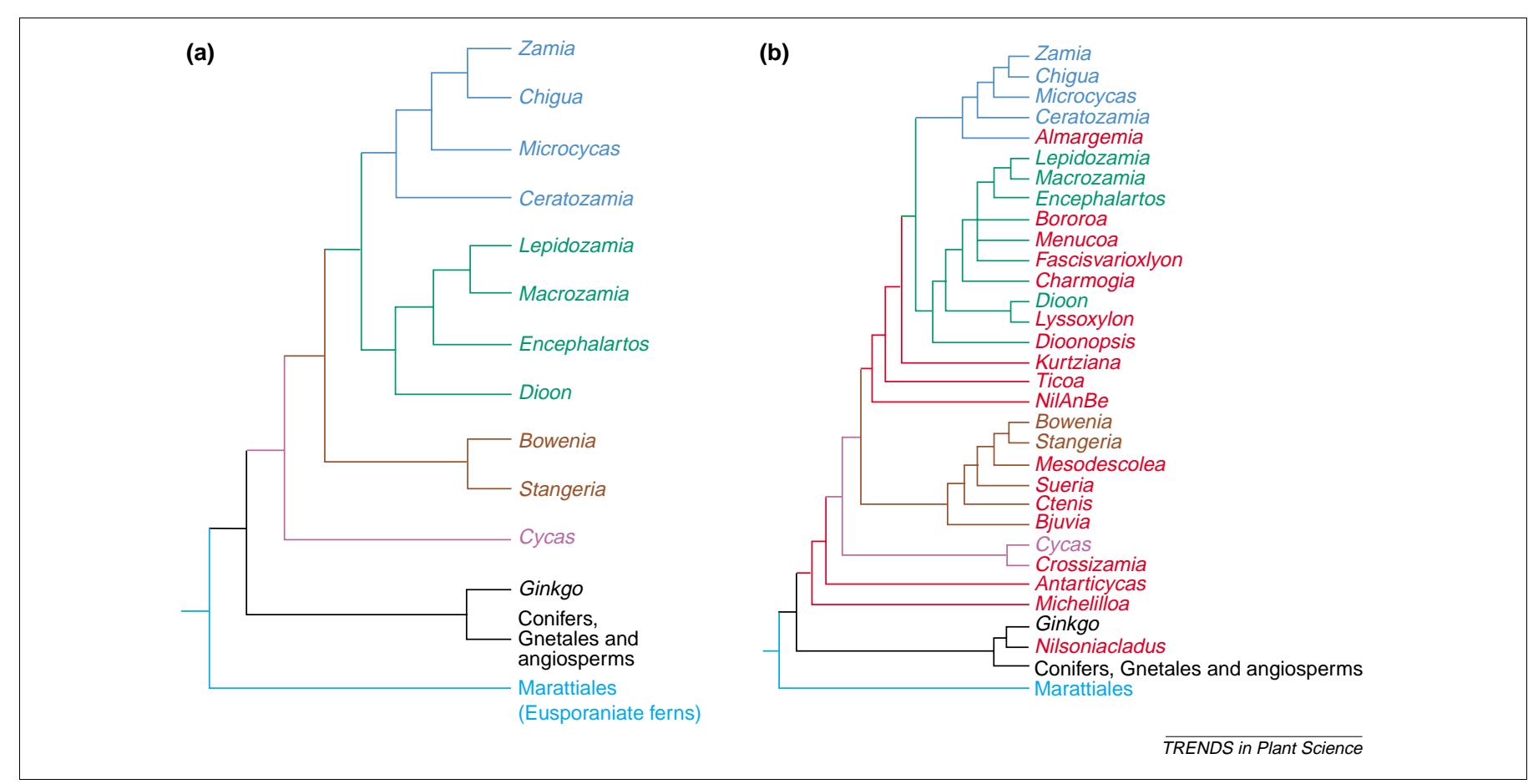

Fig. 2. Cladograms of cycad genera based upon morphological characters. (a) Living genera only and outgroups. (b) Living and fossil genera, modified from Ref. [3]. The 11 fossil genera are indicated in red. Cycads are well represented in the fossil record. Some species of modern cycads, such as Cycas, appear little changed in morphology from their fossilized progenitors [9]. Note the basal placement of Cycas sp.

\section{Seed}

Seed development is triggered by pollination, and like some other gymnosperms such as ginkgo, the time between pollination and fertilization of the cycad egg can be long because the pollen tube grows slowly. Upon fertilization of the egg, an embryo is produced. Thus, the seed (fertilized ovule) involves the remarkable cohabitation of three distinct generations within a single structure. The outside (seed coat) is the $2 n$ maternal sporophyte generation, the next internal layer is the $1 n$ (gametophyte) generation, and within that, the new, $2 n$ embryo generation. Again, with its likely designation as the oldest living spermatophyte, seed development is at its least-derived state among present-day spermatophytes in cycads.

\section{Cycad 'endosperm'}

During early development, the megagametophyte undergoes repeated free nuclear divisions, in the absence of cell division, to produce a COENOCYTIC megagametophyte. An evolutionary association between the free nuclear gametophyte stage in cycads has been made with the free nuclear stage during angiosperm endosperm development [2]. Both tissues serve a nutritive role for the embryo and both the megagametophyte and endosperm undergo cellularization later in development. However, the megagametophyte is haploid (as are all gametophytes) and the true endosperm of angiosperms is triploid from a second fertilization event. Furthermore, endosperm development in angiosperms initiates post-fertilization, whereas in cycads the megagametophyte is largely developed before fertilization. Consequently, if fertilization fails, megagametophyte production will have been a waste of resources. Thus, nutritive tissue formation in gymnosperms is tied to pollination whereas in angiosperms it is tied to fertilization. Future studies in cycad megagametophyte development might help us to understand the evolution of the angiosperm endosperm.

\section{Sporophylls}

Ovules are believed to have evolved from megasporangia borne on leaves, termed 'phyllospory', reminiscent of the placement of sporangia on fern leaves. Phyllospory is most evident in the genus Cycas, the least-derived genus in the Cycadales, in that the ovules develop at the base of leaflike structures called SPOROPHYLLS (Fig. 3b,c). The leaflike (pinnatifid) characteristics of a cycad sporophyll are evident in most Cycas species, where reduced, but distinct PINNAE are present at the apex of the sporophyll (Fig. 3c). Such pinnae could be remnants of reduced pinnately compound leaves common in cycadeoids, seed ferns and ferns. Alternatively, the pinnae found in modern Cycas sporophylls might be derived from an ENTIRE lamina [10].

\section{Cones}

All species of cycads produce cones, except for female members of Cycas, which produce a loose cluster of sporophylls. Data indicates that the typical determinate cone in more advanced cycad genera such as Zamia (Fig. 3d), is derived from an indeterminate axis of spirally arranged sporophylls similar to those found in Cycas (Fig. 3c) [22]. In more evolved gymnosperms (Coniferales), the ovuliferous scales are not MEGASPOROPHYLLS, but entire modified determinate branch systems known as seed-scale complexes [21]. For those studying the evolution of cones and flowers, the change from leaf-like reproductive structures into cones is of great interest, both from a morphological perspective and the evolution of the genes involved. 

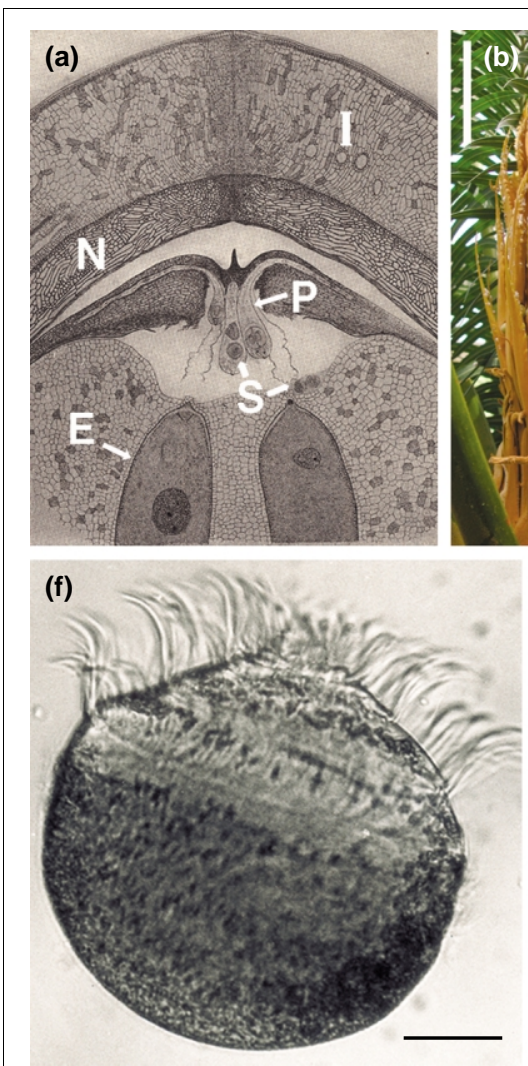
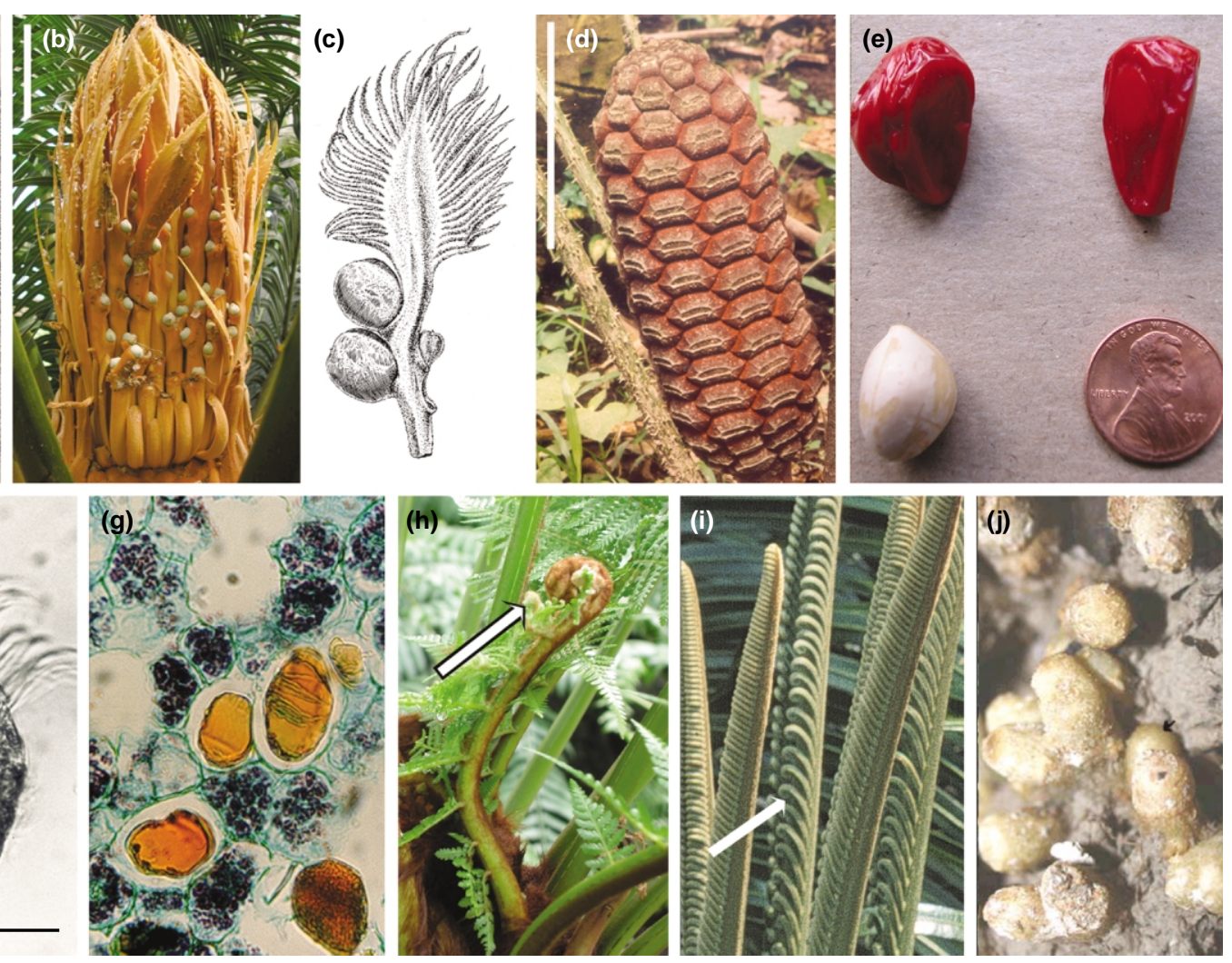

Fig. 3. Plesiomorphic and apomorphic characters in cycads. (a) A classic illustration, reproduced, with permission, from [4] showing a longitudinal section of a cycad ovule during fertilization. Abbreviations: I, integument; N, nucellus; P, pollen tube; S, spermatozoids; E, egg (housed in archegonium). Note pollen tubes containing spermatozoids. Other pollen tubes have released their gametes. (b) Loose cluster of sporophylls in Cycas rumphii with fertile, pea-sized ovules at the margins. Note some sporophylls in the forefront have been removed for clearer viewing. Scale bar $=8 \mathrm{~cm}$. (c) Illustration of Cycas revoluta sporophyll with developing seeds. Note the distinct pinnae, which suggest that they originate from modified, pinnately compound leaves. (d) Cone. In more advanced cycad genera the sporophylls are further modified into tightly appressed bract-like structures to form cones as shown in Zamia encephalartoides. Scale bar $=10 \mathrm{~cm}$. (e) Seeds from Zamia furfacaea. The two upper seeds show the fleshy sarcotesta, a tissue that aids seed dispersal by being a food reward and pre-dates the evolution of the ovary, or true fruit of angiosperms. The sarcotesta has been removed from the bottom seed to reveal the hard sclerotesta. (f) Multi-ciliated spermatozoid. The presence of spermatozoids in cycads links seed plants to the lower plants, which are dependent on water for fertilization [2]. Scale bar $=80 \mu \mathrm{m}$. (g) Cross section of the megasporophyll showing numerous gold cells (idioblasts). Gold cells contain neurotoxic, protective compounds that play a key role in beetle pollination [28]. (h) Unfurling of coiled (circinate vernation) fern leaf (Dicksonia antartica). Arrow points to coiled portion of leaf. (i) Similarly, circinate vernation in Cycas rumphii leaflets. Arrow points to tightly coiled developing leaflets. (j) Coralloid root of Zamia sp., which house nitrogen-fixing Cyanobacteria.

\section{Sarcotesta: a fruitful innovation}

The carpel (ovary) is the defining character of angiosperms. With the evolution of the ovary came a stunning variety of fruit types to aid seed dispersal. However, the production of tissue that appears 'fruity' is an innovation found in gymnosperms. The cycad seed coat, which develops from the integument, consists of three layers: the fine inner endotesta, the middle rigid sclerotesta and the outer, typically fleshy sarcotesta (reviewed in [2]). As an innovation, the sarcotesta represents an important adaptation towards vector-assisted seed dispersal. In cycads, the sarcotesta becomes fleshy and edible to some animals, and is often brightly colored to signal that it is 'ripe' (Fig. 3e).

\section{Pollen}

Cycads are the oldest, extant pollen-producing plants. Before the evolution of pollen, fertilization was water dependant. By packaging the male gamete into pollen, plants could use vectors (such as water, wind and animals) for long-distance transport of the male gamete to the egg. One of the most significant discoveries in plant evolution came from the astonishing observation that cycads (and Ginkgo) produce flagellated gametes [23] (Fig. 3f) in the growing pollen tube (Fig. 3a). This discovery established the ancestral connection between non-seed and seed plants. Spermatozoids are not present in Coniferales, Gnetales or angiosperms, revealing that cycads and ginkgo represent the last vestiges of motile sperm production in plants.

\section{Pollinators}

Studies in cycads provide a window into the evolution of early pollinators. For decades it was hypothesized that cycads are wind pollinated [4], until pollination was shown to be ENTOMOPHILOUS because weevils are effective pollinators $[24,25]$. The weevil life cycle is highly interdependent with cycad growth and reproduction. Weevils derive both food and shelter in the male cone tissue throughout their life cycle.

Cycads have developed specialized, toxin-containing Idioblasts known as 'gold cells' (Fig. 3g) (because of their natural auburn color), which are believed to promote outcrossing (reviewed in [26]). In male cones, idioblasts are intact and lack PLASMODESMATA, whereas in the female cone, the idioblasts have plasmodesmata and are sometimes ruptured, releasing their poisonous contents, including neurotoxins [27]. Consequently, although weevils 
avidly consume male cone tissue, the gold cells remain benignly intact in their gut. The weevils visit and pollinate the female cone but refrain from eating the megasporophyll, which remains intact to nourish the developing seed [28]. Beetle pollination occurs in a wide cross-section of cycad genera (cycads and their pollinators are reviewed in [29]). Some cycads have changed little in morphology from their progenitors in the lower Permian [9]; therefore, it is possible that entomophilous pollination has existed for nearly 300 million years. However, the presence of weevils in the fossil record only dates back to the Mesozoic [29], leaving open the possibility that some other animal or agent was the original pollinator of cycads.

\section{Plesiomorphic versus apomorphic traits in vegetative structures \\ Dichotomous branching}

Studies in cycads might help us to understand the evolution of axial branching that exists in some ferns and gymnosperms and angiosperms. ISOTOMOUs branching is the ancestral state. Cycads exhibit vegetative isotomous branching (with the occasional adventitious branch) [22]. If cycads are the sister group to the seed plants, then AXILLARY branching is a SYNAPOMORPHY for a clade composed of Ginkgo, Conifers, Gnetales and flowering plants. If Gymnosperms are monophyletic and are the sister group to the flowering plants, then axillary branching must have evolved twice, once in Gymnosperms starting with Ginkgo and once in flowering plants as has been suggested by others [11].

\section{Circinate vernation}

A striking characteristic of cycad growth habit or morphology is their resemblance to the folded developing leaves of ferns. Coiling in immature, developing leaves in ferns is otherwise known as CIRCINATE VERNATION (Fig. 3h). Leaves in some cycad species with their circinate pinnae partly resemble circinate young fern leaves (Fig. 3i) [4,30].

\section{Coralloid roots}

The symbiotic relationship between plants and nitrogenfixing bacteria must have appeared early in land plant evolution because it is found in liverworts and ferns. Cycads have specialized 'CORALLOID' ROOTS (Fig. 3j), where nodule-like structures house nitrogen-fixing cyanobacteria. Soon after seed germination, AGRAVITROPIC roots develop initially free of bacteria [31]. Although the exact mode of entry into uninfected coralloid roots is unknown, it probably occurs through wounds or natural openings $[32,33]$. Experiments have confirmed the specificity of this relationship by inoculating aseptically cultured cycad roots with the cyanobacteria [33,34]. The study of the molecular and physiological controls regarding nodule formation and infection in cycad coralloid roots could be useful to understand the evolution of root-based nitrogenfixing symbiotic systems of more-derived plants.

\section{Molecular studies in cycads}

Few studies have examined the role that molecular regulators play during cycad development. We argue that cycads also merit detailed, evolutionary developmental analysis because of their placement at a key node in plant evolution. Of the many innovations listed above, the cycad reproductive structures would be a good place to begin this analysis.

From the list of genes involved in controlling reproductive growth, cycad ORTHOLOGS of the ABC lineage of MADS box genes, which in angiosperms are homeotic regulators of floral organogenesis (reviewed in [35]), await analysis in cycads. Orthologous B and $\mathrm{C}$ genes have been purified from the more-derived gymnosperms (Gnetales and Coniferales) [36,37]. The B ortholog is expressed in male organs, whereas the $\mathrm{C}$ ortholog is expressed in both male and female organs [38], which is similar to angiosperms. This similarity led to the conclusion that genes specifying male organs ( $\mathrm{B}$ and $\mathrm{C}$ gene expressed simultaneously) and female organs ( $\mathrm{C}$ gene alone) evolved before the emergence of the common ancestor of extant seed plants [38]. To test or refute this theory, the discovery and analysis of $\mathrm{B}$ and $\mathrm{C}$ genes in cycads is paramount considering its likely placement as the oldest, living seed plant. Recently, MADS box genes, including the agamous (C clade) ortholog have been discovered in Ginkgo [39]. Two reports mention that MADS box genes have been cloned in Zamia [37] and in Cycas [40], but expression data has not been reported. The ABC lineage is missing from ferns [41], therefore cycads need to be analyzed to explore the origins of the $\mathrm{ABC}$ genes to confirm or refute $\mathrm{B}$ and $\mathrm{C}$ gene expression patterns found in Gnetum and Conifers.

Besides ABC genes, HOX genes, such as KNOX-1, warrant analysis in cycads. KNOX-1 controls cell identity in the shoot meristem (reviewed in [42]). In most vascular plants, KNOX1 is expressed in the shoot apical meristem and down regulated in the leaf primordia during its formation, as is the case for simple leaves. During complex leaf formation $K N O X 1$ is reactivated at a later stage of primordia development [43]. A cross survey of vascular plants confirmed that this expression pattern is found in nearly all seed plants (except pea [44]), including the pinnately complex leaf in the cycad genus Zamia [45].

\section{Defense or signaling: cycad derived neurotoxins}

Cycads are a rich source of secondary compounds, some of which are poisonous [2]. Marjorie Whiting was the first to propose that cycads could be responsible for Guam's dementia [5]. The subsequent search for a neurotoxic compound in cycads lead to the identification of a novel non-protein amino acid called BMAA (beta-methylaminoL-alanine) [8]. Additional studies have purified other possible neurotoxic agents from cycads, including methylazoxymethanol (MAM)-glycocides [46] and sterol beta-Dglucoside [47]. However, of these candidate neurotoxins derived from cycads, BMAA has been the most thoroughly investigated (reviewed in [7]).

When tested on isolated animal neurons, BMAA acts as an agonist of GLUTAMATE RECEPTORS $[48,49]$. On primates, BMAA causes convulsions and neurodegeneration [50]. However, this response is immediate, whereas Guam's dementia is a latent disease, appearing many years after exposure. Furthermore, standard washing of cycad meal during food preparation effectively removes most of the 
BMAA - lowering the concentration of BMAA to a level considered to be non-hazardous [51,52]. Possibly then, the neurodegeneration identified by Whiting in the Chamorro population of Guam comes from chronic, low-level exposure to BMAA. An alternative theory is that BMAA exposure is indirect - from eating bats (another component of the Chamorro diet) that consumed cycad seeds [53]. This theory is also controversial [54]. In the 40 years since Whiting's first observation, definitive proof that BMAA is the cause of Guam's dementia is lacking. The cause of Guam's dementia might forever remain unknown because most victims are now elderly [55].

Although the causative role of BMAA as the source of Guam's dementia remains cryptic, a new question has emerged: what is the role of BMAA in plants? BMAA is an agonist of glutamate receptors. Genes similar to human glutamate receptors have been cloned in plants (Arabidopsis) [56-58]. Supplying exogenous BMAA to growing Arabidopsis seedlings blocks light-induced hypocotyl shortening and cotyledon expansion. At low concentrations $(50 \mu \mathrm{M})$, BMAA induces hypocotyl elongation that is two to three times longer than that in untreated plants when grown in the light. At higher concentrations BMAA is inhibitory to root as well as to shoot growth [59]. These effects suggest that glutamate, and/or BMAA, could have a role in signal transduction in Arabidopsis [56,59]. Isolated Arabidopsis mutants resistant to the effects of BMAA might identify the endogenous components of a BMAAtargeted pathway in Arabidopsis [59]. Evidence indicates that BMAA acts as an agonist of an Arabidopsis glutamate receptor gene (GLR1.1) [60].

Recently, glutamate receptor genes have been purified from cycads in BMAA-producing tissue (E.D. Brenner, unpublished). This raises some important questions regarding the endogenous role of BMAA in cycads. Is BMAA merely involved in protecting the plant against predators? Or does BMAA have a physiological role in cycads as evidenced from its effects on Arabidopsis? Cycads produce BMAA at high levels - up to $0.24 \mathrm{mg} \mathrm{g}^{-1}$ of the total weight in certain tissues [61]. BMAA is sequestered in specialized idioblasts [28]. Could BMAA be sequestered to protect other cells from its affects? However, in the female megagametophyte, these idioblasts appear lysed, presumably dispensing their contents [28], suggesting that cycads (and their glutamate receptors) have evolved mechanisms to deal with the potential toxic effects of BMAA.

Future studies should attempt to define the role of glutamate receptors in plants, as well as the role of BMAA, not only in defense against predators, but possibly as an endogenous signaling compound.

\section{Future directions in cycad studies}

Cycads are living fossils, with evolutionary and medicinal relevance. Our challenge is to use present-day technology to study cycads. Cycads are not a 'model organism' - the genomes are large, the lifecycle is slow and the genetics impossibly arduous. However, cycads offer some advantages that are lacking in Arabidopsis, such as ease of histology and biochemical studies. Structures in cycads are big, therefore tissue availability is not a limiting factor.
For instance, cycad spermatazoids and eggs are the largest of any living plant [2] and can be seen with the naked eye. The ability to generate EST libraries made specifically from 'giant' (relative to other plants) structures becomes possible. With accumulating sequence data from moreand less-derived plants (including two completely sequenced plant genomes [62,63]), comparative genomics can be used to study the molecular regulation of signaling and metabolism, as well as evolution and development in cycads. A first step towards that goal is the current production and analysis of ESTs from cycads by the Plant Genomics Consortium, which consists of The New York Botanical Garden, New York University, Cold Spring Harbor and The New York Museum of Natural History. Thus, we should be able to respond to the challenge to explore these medicinally and evolutionarily important, ancient plants.

\section{Acknowledgements}

We dedicate this paper to the memory of Knut Norstog who passed away on 18 June 2003. We thank Francesco Coelho and the Montgomery Botanical Center, FD for providing plant tissue; Trevor Stokes for reviewing the manuscript and Eduardo de la Torre for helpful discussions and Ayelet Levy for technical help. We would particularly like to thank Gloria Coruzzi for her assiduous support in this project. Funding for this work comes from the Plant Genomics Consortium, which is made possible by the generosity of the Altria Group, Inc., The Mary Flagler Cary Charitable Trust, The Eppley Foundation for Research, Inc., The Leon Lowenstein Foundation, Inc., The Ambrose Monell Foundation and The Wallace Genetic Foundation, Inc.

\section{References}

1 Norstog, K.J. (2003) Foreword. In Cycads: Status, Survey, and Conservation Action Plan (Donaldson, J., ed.), pp. 3-8, IUCN/SSC, Gland, Australia

2 Norstog, K.J. and Nicholls, T.J. (1997) The Biology of the Cycads, Cornell University Press, Ithaca, NY, USA

3 Stevenson, D.W. and Artabe, A.E. (1995) Fossil and extant cycads: a cladistic analysis. Am. J. Bot. 89 (Suppl.), 235

4 Chamberlain, C. (1919) The Living Cycads, University of Chicago Press, Chicago, IL, USA

5 Whiting, M.G. (1963) Toxicity of cycads. Econ. Bot. 17, 271-302

6 Sacks, O.W. (1997) In The Island of the Colorblind (Knopf, A.A., ed.), Distributed by Random House, New York, NY, USA

7 Duncan, M.W. (1993) Cycads as a possible cause of neurological disorders in the Western Pacific. In Proceedings of CYCAD 90, the Second International Conference on Cycad Biology (Stevenson, D.W. and Norstog, K.J., eds), pp. 19-23, Palm \& Cycad Societies of Australia, Milton, Queensland, Australia

8 Vega, A. and Bell, E.A. (1967) Alpha-amino-beta-methylaminopropionic acid, a new amino acid from seeds of Cycas circinalis. Phytochemistry 6, 759-762

9 Gao, Z. and Thomas, B.A. (1989) A review of fossil cycad megasporophylls, with new evidence of Crossozamia pomel and its associated leaves from the lower Permian of Taiyuan, China. Rev. Palaeobot. Palynol. 60, 205-223

10 Mamay, S.H. (1969) Cycads: fossil evidence of late paleozoic origin. Science 164, 295-296

11 Doyle, J.A. (1998) Phylogeny of vascular plants. Annu. Rev. Ecol. Syst. $29,567-599$

12 Stevenson, D. (1990) Morphology and systematics of the Cycadales. Mem. N. Y. Bot. Gard. 57, 8-55

13 Magollón, S. and Sanderson, M.J. (2002) Relationships among seed plants inferred from highly conserved genes: sorting confilicting phylogenetic signals among ancient lineages. Am. J. Bot. 89, 1991-2006

14 Schmidt, M. and Schneider-Poetsch, H.A. (2002) The evolution of gymnosperms redrawn by phytochrome genes: the Gnetatae appear at the base of the gymnosperms. J. Mol. Evol. 54, 715-724

15 Chaw, S.M. et al. (2000) Seed plant phylogeny inferred from all three 
plant genomes: monophyly of extant gymnosperms and origin of Gnetales from conifers. Proc. Natl. Acad. Sci. U. S. A. 97, 4086-4091

16 Bowe, L.M. et al. (2000) Phylogeny of seed plants based on all three genomic compartments: extant gymnosperms are monophyletic and Gnetales' closest relatives are conifers. Proc. Natl. Acad. Sci. U. S. A 97, 4092-4097

17 Qiu, Y.L. et al. (2000) Phylogeny of basal angiosperms: analyses of five genes from three genomes. Int. J. Plant Sci. 161, S3-S27

18 Pryer, K.M. et al. (2002) Deciding among green plants for whole genome studies. Trends Plant Sci. 7, 550-554

19 Cronk, Q.C.B. (2001) Plant evolution and development in a postgenomic context. Nat. Rev. Genet. 2, 607-619

20 Nishida, H. et al. (2003) Palaeobotany: swimming sperm in an extinct Gondwanan plant. Nature 422, 396-397

21 Foster, A.S. and Gifford, E.M. (1974) Comparative Morphology of Vascular Plants, W. H. Freeman and Company, New York, NY, USA

22 Stevenson, D.W. ed. (1988) Strobilar Ontogeny in the Cycadales Fischer, G, Berlin, Germany

23 Ikeno, S. and Hirase, S. (1897) Spermatozoids in gymnosperms. Ann. Bot. 11, 344-345

24 Norstog, K.J. et al. (1986) The role of beetles in the pollination of Zamia furfuraceae L. fil. (Zamiaceae). Biotropica, 18

25 Tang, W. (1987) Insect pollination in the cycad Zamia pumila (Zamiaceae). Am. J. Bot. 74, 90-99

26 Stevenson, D.W. et al. (1998) Pollination biology of cycads. In Reproductive Biology (Owens, S.J. and Rudall, P.J., eds), pp. 277-294, Royal Botanic Gardens, Kew, Surrey, UK

27 Vovides, A.P. et al. (1993) Histological changes during maturation in male cones of the cycad Zamia furfuracea and their significance in relation to pollination biology. Bot. J. Linn. Soc. 111, 241-252

28 Norstog, K.J.et al. (1993) Toxicity and insect-cycad symbiosis in Zamia furfuracea. In Proceedings of CYCAD 90, the Second International Conference on Cycad Biology (Stevenson, D.W. and Norstog, K.J., eds), pp. 42-50, Palm \& Cycad Societies of Australia, Milton, Queensland, Australia

29 Schneider, D. et al. (2002) Cycads: their evolution, toxins, herbivores and insect pollinators. Naturwissenschaften 89, 281-294

30 Stevenson, D.W. (1981) Observations on ptyxis, phenology, and trichomes in the Cycadales and their systematic implications. Am. J. Bot. 68, 1104-1114

31 Marshall, J. et al. (1989) Comparative morphological and physiological studies on cyanobionts of Encephalartos transvenosis. S. Afr. J. Bot. 55, $574-580$

32 Nathanielsz, C.P. and Staff, I.A. (1975) Mode of entry of blue-green algae into the apogeotropic roots of Macrozamia communis. Am. J. Bot. $62,232-235$

33 Ow, M.C. et al. (1999) Reconstitution of a cycad-canobacterial association. Symbiosis 27, 125-134

34 Grobbelaar, N. and Marshal, J. (1993) Specificity of the cycadcyanobiont symbiosis. In Proceedings of CYCAD 90, the Second International Conference on Cycad Biology (Stevenson, D.W. and Norstog, K.J., eds), pp. 162-164, Palm \& Cycad Societies of Australia, Milton, Queensland, Australia

35 Goto, K. et al. (2001) Turning floral organs into leaves, leaves into floral organs. Curr. Opin. Genet. Dev. 11, 449-456

36 Vergara-Silva, F. et al. (2000) MADS-box genes: development and evolution of plant body plans. J. Phycol. 36, 803-812

37 Theissen, G. et al. (2000) A short history of MADS-box genes in plants. Plant Mol. Biol. 42, 115-149

38 Winter, K.U. et al. (1999) MADS-box genes reveal that gnetophytes are more closely related to conifers than to flowering plants. Proc. Natl. Acad. Sci. U. S. A. 96, 7342-7347

39 Jager, M. et al. (2003) MADS-box genes in Ginkgo biloba and the evolution of the AGAMOUS Family. Mol. Biol. Evol. 20, 842-854

40 Zhang, P. et al. (2002) Cloning and characterization of Fortune-1, a novel gene with enhanced expression in male reproductive organs of Cycas edentata. Mech. Dev. 114, 149-152
41 Munster, T. et al. (1997) Floral homeotic genes were recruited from homologous MADS-box genes preexisting in the common ancestor of ferns and seed plants. Proc. Natl. Acad. Sci. U. S. A. 94, 2415-2420

42 Barton, M. (2001) Leaving the meristem behind: regulation of KNOX genes. Genome Biol. 2 REVIEWS1002 (http://genomebiology.com/ 2001/2/1/REVIEWS/1002)

43 Bharathan, G. and Sinha, N.R. (2001) The regulation of compound leaf development. Plant Physiol. 127, 1533-1538

44 Gourlay, C.W. et al. (2000) Pea compound leaf architecture is regulated by interactions among the genes UNIFOLIATA, cochleata, afila, and tendril-lessn. Plant Cell 12, 1279-1294

45 Bharathan, G. et al. (2002) Homologies in leaf form inferred from KNOXI gene expression during development. Science 296, 1858-1860

46 Seawright, A.A. et al. (1999) Recent toxicity stud ies in animals using chemicals derived from cycads. In Biology and Conservation of Cycads - Proceedings of the Fourth International Conference on Cycad Biology (Chen, C.J., ed.), pp. 345-353, International Academic Publishers, Beijing, China

47 Khabazian, I. et al. (2002) Isolation of various forms of sterol betaD-glucoside from the seed of Cycas circinalis: neurotoxicity and implications for ALS-parkinsonism dementia complex. J. Neuroc hem. 82, 516-528

48 Copani, A. et al. (1990) Beta- $N$-methylamino-L-alanine (L-BMAA) is a potent agonist of 'metabolotropic' glutamate receptors. Eur. J. Pharmacol. 181, 327-328

49 Manzoni, O.J. et al. (1991) Beta- $N$-methylamino-L-alanine is a lowaffinity agonist of metabotropic glutamate receptors. Neuroreport 2, 609-611

50 Spencer, P.S. et al. (1987) Guam amyotrophic lateral sclerosisParkinsonism-dimentia linked to a plant excitant neurotoxin. Science 237, 517-522

51 Duncan, M.W. et al. (1990) 2-Amino-3-(methylamino)-propanoic acid (BMAA) in cycad flour: an unlikely cause of amyotrophic lateral sclerosis and Parkinsonism-dementia of Guam. Neurology 40, 767-772

52 Wilson, J.M. et al. (2002) Behavioral and neurological correlates of ALS-Parkinsonism dementia complex in adult mice fed washed cycad flour. Neuromolecular Med. 1, 207-221

53 Cox, P.A. and Sacks, O.W. (2002) Cycad neurotoxins, consumption of flying foxes, and ALS-PDC disease in Guam. Neurology 58, 956-959

54 Chen, K.M. et al. (2002) Cycad neurotoxin, consumption of flying foxes, and ALS/PDC disease in Guam. Neurology 59, 1664-1665

55 Galasko, D. et al. (2002) Clinical features and changing patterns of neurodegenerative disorders on Guam, 1997-2000. Neurology 58, 90-97

56 Lam, H.M. et al. (1998) Glutamate-receptor genes in plants. Nature $396,125-126$

57 Lacombe, B. et al. (2001) The identity of plant glutamate receptors. Science 292, 1486-1487

58 Chiu, J.C. et al. (2002) Phylogenetic and expression analysis of the glutamate-receptor-like gene family in Arabidopsis thaliana. Mol. Biol. Evol. 19, 1066-1082

59 Brenner, E.D. et al. (2000) Arabidopsis mutants resistant to S(+)-betamethyl-alpha, beta-diaminopropionic acid, a cycad-derived glutamate receptor agonist. Plant Physiol. 124, 1615-1624

60 Kang, J. and Turano, F.J. (2003) The putative glutamate receptor 1.1 (AtGLR1.1) functions as a regulator of carbon and nitrogen metabolism in Arabidopsis thaliana. Proc. Natl. Acad. Sci. U. S. A. 100, 6872-6877

61 Duncan, M.W. et al. (1989) Quantification of the putative neurotoxin 2-amino-3-(methylamino)propanoic acid (BMAA) in Cycadales: analysis of the seeds of some members of the family Cycadaceae. J. Anal. Toxicol. 13, 169-175

62 The Arabidopsis Genome Initiative, (2000) Analysis of the genome sequence of the flowering plant Arabidopsis thaliana. Nature 408, $796-815$

$63 \mathrm{Yu}$, J. et al. (2002) A draft sequence of the rice genome (Oryza sativa $\mathrm{L}$. ssp. indica). Science 296, 79-92 